\title{
Green Entrepreneurship \& Corporate Social Responsibility: Comparative and Correlative Performance Analysis
}

\author{
Vasiliki A. Basdekidou ${ }^{1}$ \\ ${ }^{1}$ SRFA Aristotle University of Thessaloniki, Greece \\ Correspondence: Vasiliki A. Basdekidou, Special Research Fund Account (E $\Lambda$ KE), Aristotle University of \\ Thessaloniki, Greece. Tel: 30-697-277-5475. E-mail: Vasiliki.Basdekidou@ gmail.com
}

Received: September 8, 2017

Accepted: October 27, 2017

Online Published: October 30, 2017

doi:10.5539/ijef.v9n12p1

URL: https://doi.org/10.5539/ijef.v9n12p1

\begin{abstract}
In investment and trading, different CSR/CSE (Corporate Social Responsibility/Corporate Social Entrepreneurship) moral ethical firms, categorized in a number of groups, may be suitable for different financial instruments (i.e. USA sector ETFs) and different market volatility situations. For the purpose of this article we first (i) analyze the trading return performance of four CSR/CSE categories (in particular: green building, green products, green services, and green transportation); and then (ii) examine and comment the correlation between the market performance of a number of firms belonging in these four CSR/CSE categories and historical ETF market volatility. Finally, we (iii) suggest CSR firms as trading tools according to dominant market volatility. Other CSR/CSE categories (like: sustainability, executive sustainability, renewable energy, green IT, green ICT, etc.) would be examined in future research by following the introduced by this paper approach. Paper concludes that, in relatively less volatile markets the Green Transportation CSR/CSE ethical firms display better results. On the other hand, in strong market volatile situations it is better to trade Green Products CSR/CSE and Green Services CSR/CSE ethical firms. Finally, the Green Building CSR/CSE ethical firms are uncorrelated with the market volatility, as well as their performance is poor in all market cases.
\end{abstract}

Keywords: green entrepreneurship, corporate social responsibility, corporate social entrepreneur, ethical investing, historical market volatility

JEL Classification: G10, G14, G18, M20

\section{Introduction}

The main goal of this paper is to suggest and propose CSR/CSE (Corporate Social Responsibility / Corporate Social Entrepreneurship) ethical firms as trading tools according to dominant market volatility, after the examination and comment of the correlation between a number of US CSR/CSE ethical firms and the underlined market volatility (Ang et al., 2006; Angel \& Rivoli, 1997; Leung, Lorig, \& Pascucci, 2015; Little, 2010). For this purpose, firstly, a performance analysis has been conducted and four green CSR/CSE categories (Green Building, Green Products, Green Services, and Green Transportation) were considered on selecting the CSR/CSE ethical firms for this performance analysis (Note 1; Note 2).

Green Building: Green Building is a modern design concept in Architecture and a construction practice in (Civil) Engineering of increasing the efficiency of buildings and their use of energy, water, wood, and other materials; as well as of reducing building impacts and influences on human health and the environment.

Green Products: Green Products (usually Natural and Organic Products) are food and non-food products as well, which have been involved (designed, produced, processed and transported) in compliance with laws, regulations, benchmarks, and agreements that typically exclude ingredients and/or manufacturing methods and techniques of impurity, poison, toxic, toxin, pollutant, and harmful chemicals.

A typical Green Products CSR/CSE firm: The Bionic Power Inc. (www.Bionic-Power.com). Bionic Power, a high-tech startup based on British Columbia - Canada, makes wearable technology for charging batteries. Bionic-Power focused on providing cost-effective and reliable energy to people whose lives or quality of life depend on portable power. Recently, it is focused on developing the so-called PowerWalk® Kinetic Energy Harvester (KEH) for the U.S. military. Also, Bionic Power's Biomechanical Energy Harvester (BEH) uses the energy created by the human body during the walking or running process in order to charge a number of portable 
compact batteries. The BEH device, which after development should weigh about two pounds, is geared towards people need an easy, cheap, and portable power. Importing disposable batteries could costs heavily (in terms of transportation fuel). Target and spot markets include the military, ICT companies, public safety officials, first responders, and others who need charged batteries during blackouts.

Green Services: Green Services is the concept, dogma or practice of dynamic and effective action (including direct- and indirect-actions) which have been involved, designed, produced and processed as a means of achieving personal, political, cultural, and social services.

Green Transportation: Green Transportation is an essential part of urban and sub-urban design and in creating livable cities, landscapes and rural areas. There are a number of beneficial forms of green transportation that support and enhance walkable urbanism. These green transportation options make our lives easier, reduce traffic jam, reduce human dependence on vehicles (cars and buses) and oil or gas, are safer and less costly, help save the cities, environment, and planet Earth, and make life more fun and healthy as well! The greenest and most sustainable forms of transportation are trains, bicycles, and walking. Some of the world's best and fastest trains have been in operation for more than 30 years in USA, more than 25 years in Europe, and more than 40 years in Japan. These include innovative high-speed trains like the futuristic Euro star, the French TGV, the Japanese bullet train, etc.; and also regional trains, metro, light rail, trams, trolleys, streetcars, and people movers. Clean electric trains are a major form of daily transportation in numerous countries, and are the single most powerful transportation choice that can solve serious mobility, travelling, energy, environmental, moving, economic, health, and social problems on a global scale.

A typical Green Transportation CSR/CSE firm: The Feelgoodz LLC (www.FeelGoodz.com). The Feelgoodz is a startup company located in Raleigh (Wilmington) NC - USA. Feelgoodz manufactures eco-friendly shoes and footgear by using hemp, bamboo, natural rubber, and recycled paper. It is notable that $3 \%$ of its profits go to charitable sources and motivations, including the Fair Trade; and 1\% goes "For-the-Planet". Their comfortable flip-flops are all-natural and 100\% bio-degradable (ecological). The flip-flops could be huge if they gain an international market.

\section{Corporate Social Entrepreneurship (CSE)}

Corporate Social Entrepreneurship (CSE) is multi-disciplinary, relating to the fields of corporate social obligation, authority, duty, responsibility, importance, liability, trust, and sustainability. It is relevant to business and management; specifically to business ethics and conducts, conscience, sustainability, goodness, organizational behavior, enterprise, entrepreneurship, entrepreneurialism, entrepreneurism, human resources management, and business plans and strategies. The CSE concept overlaps (extend along) with sociology, ecology, anthropology, psychology, social psychology, and philosophy.

Corporate Social Entrepreneurship was first described in 2002 from a theoretical working paper which was published in the Hull University Business School Research Memoranda Series (Hemingway, 2002). In this paper, it was argued that CSR (and within that, sustainability) can also be encouraged by personal values, in addition to the more obvious economic, social, psychological, and political catalysts. This approach actually reflected the traditional philosophical and business ethics controversy regarding moral and moralistic issues (Lovell, 2002). This paper was followed by a United Kingdom conference paper which discussed the importance of managerial discretion in Corporate Social Responsibility and was published the following year in the Journal of Business Ethics (Hemingway \& Maclagan, 2004).

The term "Corporate Social Entrepreneur" was brainstormed in a paper presented at the $17^{\text {th }}$ Annual European Business Ethics Network Conference in June 2004 (Hemingway, 2004). Actually, this term "CSE" was defined and differentiated from other types of entrepreneurs such as the executive entrepreneurs, intrapreneurs, the policy entrepreneur, the psycho-entrepreneur, the global entrepreneur, and the public or social entrepreneur (Hemingway, 2004). Initially, the term related to managers, however later it was extended to include employees at any level of a firm or company, regardless of their formally appointed status. Exploratory research shows that being a senior manager is not a pre-requisite for CSE, although it is an advantage, edge, and recognition.

The Hemingway's concept of the CSE appeared and developed as a result of her own personal experience working as a marketing executive in the corporate business and it has also been the subject of some preparatory empirical and practical investigations. The conception was also inspired by Wood, who had previously referred to "Ethical training, cultural background, preference and life experience that motivate human behavior", thereby supporting Trevino's theoretical and visionary interaction model of ethical decision making in organizations (Trevino, 1986). Trevino's model included both individual and situational mediators and referees, to combine with the individual's stage of cognitive moral and ethical development, to produce either ethical or unethical 
behavior. Despite the fact that a number of studies -regarding the activities of environmental heroes and challenges at work or other change leaders and defenders- are well existed; none of these studies particularly and specifically examined the role of employees' personal values in entrepreneurial discretion with regard to CSR (always with a sustainability functionality).

Thus, the connection between philosophical ideas of moral character as an influence for CSR and the psychological notions of pro-social or pro-environmental behavior, provides a different focus from the more commonly discussed structural drivers for CSR/sustainability in business, market and management; i.e. business strategy in the form of public relations activity; encouragement from government or organizational context (see also "philanthropy" as a relative approach, theory, and perception).

\section{The Difference between the Corporate Social Entrepreneur \& the Social Entrepreneur}

The social entrepreneurship literature has largely concentrated on the voluntary, "not-for-profit" or "third" category. On the other hand: In the "for-profit" situation, the social entrepreneur is traditionally perceived as a philanthropic agent or business owner (Thompson, 2002). However, the corporate model provides a very different context. In the United Kingdom, the corporation is defined by the company's managers and shareholders in its articles of association, requiring employees to deliver returns and surplus values to shareholders, thru ought their job roles (Hemingway, 2014). The exception to this might be the UK's Co-operative Group, which describes its business as governed by a social mission and, hence, it is not responsible to shareholders for delivering profit and surplus value (Hemingway, 2014).

Consequently, unless a corporate employee has been given special appointment and award from the profit motive in order to specifically create social value, their employed work cannot be described as social entrepreneurship, despite the fact that the individual's activities outside of the workplace might be described. So, even though the majority of corporations, nowadays, claim to be fully committed to CSR, it is pushing the boundaries to describe even the most hybrid of companies (such as those dedicated to the growth of fair trade or environmentally sustainable production), as social enterprises staffed by social entrepreneurs. This is because the remit of the organization as a corporation prevents this. As a result, the CSE is unlikely to have the time or other resources to commit full scale toward a socially responsible agenda, due to organizational restrictions and clues. So, CSE is characterized by its informality, in terms of being added on to the job and performed in a cheaply-made way, which results in its amazing and awesome volatility and change ability. Furthermore in this domain, the entrepreneurial maturity and responsibility, which are required to perform, it is always a questionable concept and issue (Hemingway, 2014).

\section{Encouraging Corporate Social Entrepreneurship / Social Intrapreneurship}

If a firm or company decides to adopt corporate social entrepreneurship, there are some assets and resources that have been shown to increase the functionality of socially entrepreneurship and improve intrapreneurial activities as well. When there is a change in the environment that disconnects sanctions and rewards; then any separation or withdrawal from company's model and benchmarks (regarding moral functionalities), resulting in an undermined set of foundation assumptions, expectations, trusts and functions. Hence, when directors and employees are dissatisfied with the existing moral company's concept; then, they are more likely to take personal action, anti-company leadership, and initiative. On the other hand, if the directors and employees feel that they work in an ethic and moral environment (even without immediate guaranteed return results); then, these directors and employees are more likely to enhance social intrapreneurship functionalities resulting in positive company's returns and surplus values.

In order to calculate the historical market volatility, we use -the well known in technical analysis communityATR technical indicator divided by the average of the last 60 monthly candlestick bars. The Average True Range (ATR) is a measure of market volatility introduced first by Welles Wilder in his classic book: "New Concepts in Technical Trading Systems" (Wilder, 1978).

In fact, behind the ATR is the core True Range (TR) technical indicator, which is defined as the greatest of the following three values: (i) The current High less the current Low; (ii) The absolute value of the current High less the previous Close; and (iii) The absolute value of the current Low less the previous Close. Actually, the Average True Range (ATR) is a moving average (generally, for a 14-day period) of the True Range (TR).

\subsection{Problem Introduction}

Trading in all of its forms (i.e. investing, swing trading, short-term and intraday trading) is regarded as a temporal historical and psychological living system (Elder, 2014; Styliadis, 2007; Styliadis \& Vassilakopoulos, 2005; Tsoutsoura, 2004) with a number of time-based anomalies calling for, claiming, challenging and 
contradicting the well-known Efficient-Market Hypothesis (EMH) and initiating and launching a number of relative trading functions. According to bibliography, anomalies in the markets appear infrequently (occasionally) and challenge the EMH (Note 3).

The EMH theory claims that the current price of a security or asset reflects all public and private information, including the psychological dimension, about that security or asset. Thus, a "market" (e.g. a stock, a commodity or a 3x ETF instrument) follows the path of a Random Walk Hypothesis (RWH) (derived from a weak-form $\mathrm{EMH}$ ), the evidence, thesis and proof of which states that current prices are not dependent only on past prices and are normally distributed over time (Malkiel, 2003; Moskowitz, Ooi, \& Pedersen, 2012; Orlitzky, 2013).

In conformity to EMH and RWH theories, changes in price are due to current news or events and the psychological time, which obviously are impossible to predict in advance in market and trading concepts. The current article says that the EMH and RWH both ignore the realities of the markets (emotional factors), in that the participants are not completely rational and that current price moves are not independent of previous moves (Lou, Polk, \& Skouras, 2016; Edelen, Ince, \& Kadlec, 2015; Tsoutsoura, 2004; Ahn, Conrad, \& Dittmar, 2003; Asness, Moskowitz, \& Pedersen, 2013).

Investing and trading CSR firms is a complicated operation related on both, the firm itself (CSR category) and the underlined trading and temporal functionalities involved in the trading financial instrument, that is to say the USA sector ETF (Note 4). Hence, selecting the (leveraged) ETF in the appropriate CSR category is a great and difficult concept, but a profitable job as well (Nguyen \& Tran, 2016; Ogden \& Wu, 2013; Orlitzky, 2013; Basdekidou \& Styliadou, 2017).

\subsection{Paper's Motivation}

The main motivation of this article is the introduction, for the first time in economy and business literature, of a close-form "advise" on selecting CSR/CSE ethical firms as trading tools according to dominant market volatility. The proposed close-form "advise" has been structured after the examination and comment of the correlation between a number of US Corporate Social Responsible (CSR) ethical firms and the underlined market volatility. For this purpose, firstly, a performance analysis has been conducted regarding the involved CSR categories of the CSR ethical firms (Tsoutsoura, 2004; Orlitzky, 2013).

The link between market volatility and CSR firms' categories is complicated and it is for interest for the speculators, investors, swing traders, hedgers, long-term, mid-term and intraday traders. For instance, intraday traders in sideways range-bound markets (i.e. choppy markets) operate as speculators and usually profit from time-series momentum trading strategies at the expense of hedgers. On the other hand, swing mid-term traders, in trending markets (i.e. non-choppy markets), profit from time-series momentum trading strategies at the expense of intraday traders and long-term investors (Barclays \& Hendershott, 2003; Asness, Moskowitz, \& Pedersen, 2013; Tsoutsoura, 2004).

In this domain, the main target of the current article is contrasting and dissimilar. Actually, we investigate both cases as trading concepts: (a) whether the CSR categories involved in trading returns; and (b) whether the market volatility, historically, influence the ETFs profits. It is notable that, the results obtained do depend on the trading instrument (i.e. CSR category) and the grade of the underlined market volatility.

Therefore, always an adaptive personalized functionality is involved ("volatility" in case of the trading instrument and "user profile" for the case of the long-term investors, swing mid-term traders, intraday traders and momentary speculators) (Basdekidou \& Styliadou, 2017).

Apart from the four CSR/CSE categories investigated in this article, other CSR/CSE categories for future investigation and research are (Lou, Polk, \& Skouras, 2016):

Sustainability: In ecology, sustainability (from sustain and ability) is the property of biological systems to remain disparate, diverse, diversified and productive indefinitely. Long-lived and healthy wetlands and forests are some examples of such as sustainable biological systems. In more general terms, sustainability is the ability, strength and capacity of systems, concepts, projects, and processes.

The organizing principle for sustainability is the sustainable development, which includes the four interconnected domains: Ecology, Economics, Politics, and Culture. Sustainability science is the study of the sustainable development and the environmental science.

Executive Sustainability: Refers to powerful new strategies for enacting high-impact sustainability leadership that positions sustainability as a driver of organizational engagement, authenticity, agility, innovation, and change-capability. 
Renewable Energy: Renewable energy is this sort of energy that is collected from various renewable resources, which are naturally restored on a human time-scale. Such as renewable resources are: sunlight, wind, rain, tides, waves, and geothermal heat. Renewable energy often provides energy in four important areas: Electricity generation, Air and Water Heating/Cooling, Transportation, and Rural (i.e. off-grid) energy services.

Green IT: Green IT (i.e. the green information technology or the information technology with green functionality) is the theory and practice of environmentally sustainable computing. The Green IT concept aims to minimize the negative impact of IT operations on the environment by designing, manufacturing, operating and disposing of computers, peripherals and computer-related products in an environmentally-friendly manner. The motives behind green IT practices include: reducing the use of hazardous materials, maximizing energy efficiency during the product's lifetime, and promoting the biodegradability of unused and outdated products.

Green ICT: Green IT (i.e. the information \& communication technology with green functionality) is the theory and practice of environmentally sustainable computing networking. Green ICT aims to minimize the negative impact of ICT operations on the environment by designing, manufacturing, operating and disposing of computers, networking hardware and computer-related products in an environmentally-friendly manner.

\subsection{Paper's Structure}

The rest of the current paper is organized and formed as follows: In Section 2 ("Back-testing ETFs from four CSR/CSE categories") a relative top-down price action technical analysis approach is discussed, analyzed and demonstrated. In Section 3 ("Performance Evaluation - Results") four Tables tabulate the statistical data for these four CSR/CSE categories and then a comparative return analysis is presented. In Section 4 ("Comparative \& Correlative Performance Analysis") a comparative statistical analysis, regarding the four CSR/CSE categories, is presented and discussed. Finally, Section 5 ("Conclusions \& Future Research") summarizes the conclusions and discusses paper's innovations and contributions with future promising functionalities.

\section{Back-Testing ETFs from Four CSR/CSE Categories}

In this Section the top-down price action technical analysis market approach (based on the so-called Japanese "candlestick" representation) for the CSR/CSE ETFs is presented through the paradigm of the Time Warner (TWX) stock-instrument (Direxion, 2017; Worden, 2017).

In Figure 1 (a TC2000.com courtesy), as an example of the top-down price action technical market approach, we display the "Head \& Shoulders / neck-line" technical analysis price action pattern. The critical point in this situations is the psychological time as a warning dynamics signal (w!D) (Basdekidou \& Styliadou, 2017; Campbell et. al, 2014; Chemmanur, He, \& Hu, 2009). For more information and discussion about the so-called "psychological time" please see Livermore (1940/2001) and Lefèvre (1923/2010).

Other leveraged ETF with great CSR interest are the JNUG/JDST 3x leveraged pair (Figure 2; a TC2000.com courtesy). The JNUG instrument is the $3 x$ leveraged counterpart, while the JDST instrument is the $3 x$ inverse-leveraged counterpart of the pair. In Figure 2, the top-down price action technical market approach for the JNUG instrument is displayed. For clarity purposes we call the JNUG as "instrument" instead of as a "stock", because it's trading behavior and price action is complicated and much different than that of a normal US (NYSE, NASDAQ, NYSE Arca) stock.

Actually, these two counterparts (JNUG and JDST), despite the fact that both have the same reference, that is to say the junior gold miners GDXJ ETF (Van Eck, 2017); they operate in exactly the same percentage ratio but in an opposite manner (i.e. $+3 \mathrm{x}-3 \mathrm{x}$ ). Actually, both follow a constantly declining price action procedure and this strange behavior, explained statistically by local-stochastic volatility models; see Cheng and Madhavan (2009); and Avellaneda and Zhang (2010), is a typical technical market anomaly.

In fact, in computational finance theory, leveraged (ETF) implied volatility from (ETF) dynamics (Leung et al., 2015; Lou, Polk, \& Skouras, 2016; Domenico D'Errico, 2017; Livermore (1940/2001); Lefèvre (1923/2010); Basdekidou, 2017a; Basdekidou, 2017b; Tsoutsoura, 2004; Orlitzky, 2013). 


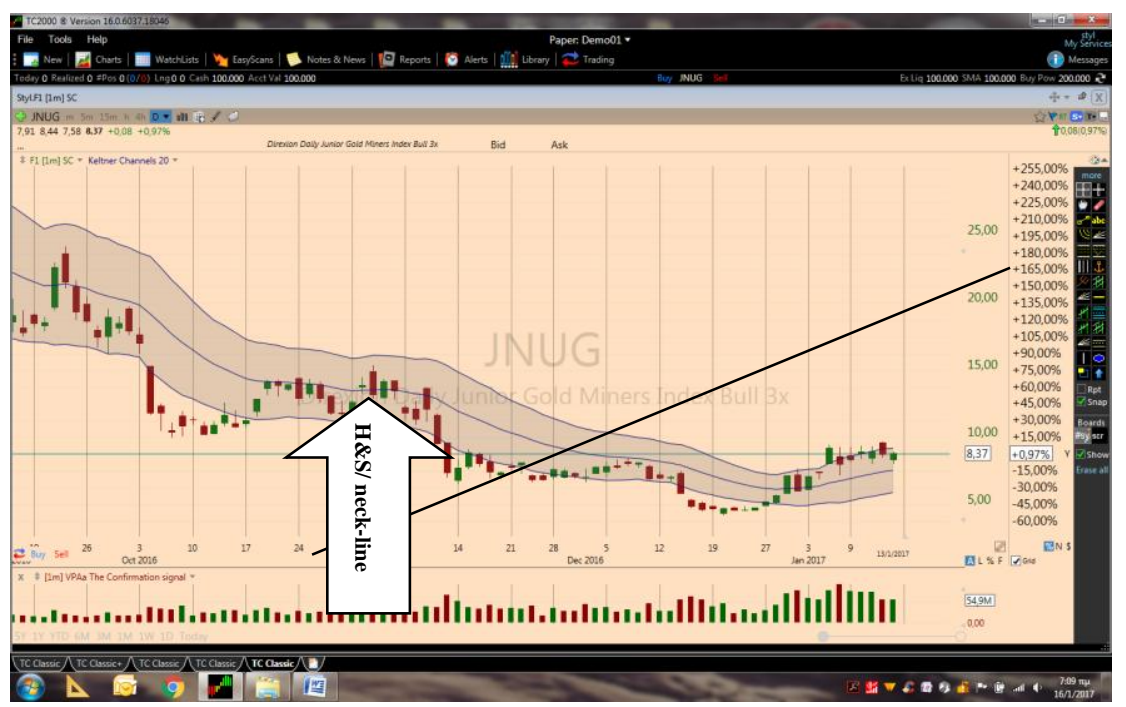

Figure 1. Gold miners juniors 3x ETF (Arca: JNUG). A Psychological time TTF as w!D signal after the appearance of "The Head \& Shoulders / neck-line" price action pattern
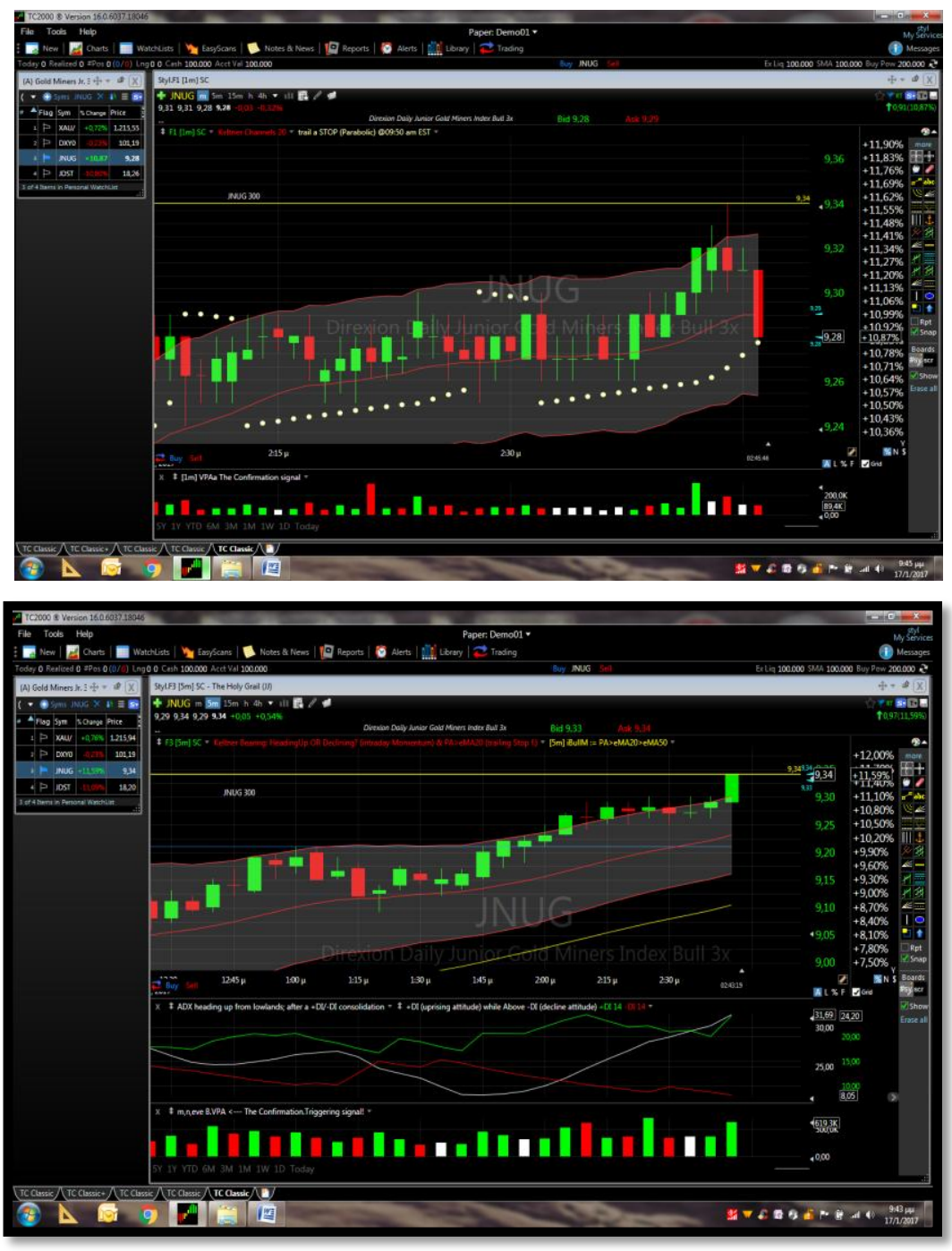

Figure 2. Gold miners juniors 3x ETF (Arca: JNUG). A Psychological time TTF as w!D signal after the appearance of: (a) "The Dark-Cloud Cover with Bearish Confirmation" candlestick pattern; and (b) "The Head \& Shoulders / neck-line" price action pattern 


\section{Performance Evaluation - Results}

According to financial literature (Blackrock, 2010; Avellaneda \& Zhang, 2010; Ogden \& Wu, 2013; Basdekidou \& Styliadou, 2017) for trading plans and strategies, a back-test procedure is an applicable performance evaluation tool offering a number of functionalities. Hence, in order to check and assess the proposed in this article trading-strategy methodology (based on CSR categories and market volatility) we have back-tested it into a 5-year and 8-month data-series for ten (10) ETFs (01.01.2012 - 31.08.2017 data). The back-test procedure has generated 203 trades and the results are presented in Tables 1,2,3, and 4; while a comparative, correlative and provisional return analysis for the back-testing procedure is discussed in the end of this Section (Domenico D’Errico, 2017; Ogden \& Wu, 2013; Basdekidou \& Styliadou, 2017; Orlitzky, 2013).

Following Table 1 is referred to the introduced CSR Green Building morality ethics firms and presents, in summary, the Hit Rate (\%) and the Average Trade (\%) for the period: $1^{\text {st }}$ January $2012-31^{\text {st }}$ August 2017 (203 trades generated) for trending (non-choppy) market situations - correlation with volatility (\%) (Barron's, 2017).

Table 1. CSR/CSE Green Building - Backtesting results for CSR ethics firms from the CSR green building category. Backtesting procedure: $1^{\text {st }}$ January $2012-31^{\text {st }}$ August 2017

\begin{tabular}{ccccc}
\hline \multicolumn{5}{c}{ Back-testing Results on USA Sector ETFs } \\
\hline USA Sector ETF & Volatility $\%$ & No. of Trades & Hit Rate \% & Average Trade $\%$ \\
\hline XLB & $9.2 \%$ & 203 & 41 & $0.40 \%$ \\
XLE & $10.4 \%$ & 203 & 36 & $-1.85 \%$ \\
XLF & $10.6 \%$ & 203 & 40 & $-0.90 \%$ \\
XLI & $7.7 \%$ & 203 & 50 & $0.94 \%$ \\
XLK & $7.5 \%$ & 203 & 40 & $0.80 \%$ \\
XLP & $5.2 \%$ & 203 & 33 & $-1.30 \%$ \\
XLU & $6.9 \%$ & 203 & 33 & $-1.32 \%$ \\
XLV & $6.7 \%$ & 203 & 38 & $-0.49 \%$ \\
XLX & $7.3 \%$ & 203 & 44 & $0.30 \%$ \\
XLY & $7.4 \%$ & 203 & 45 & $0.36 \%$ \\
\hline Average & & & 40 & $-0.31 \%$ \\
Correlation with volatility $\%$ & & & 0.11 & $-0.09 \%$ \\
\hline
\end{tabular}

Following Table 2 is referred to the introduced CSR Green Products morality ethics firms and presents, in summary, the Hit Rate (\%) and the Average Trade (\%) for the period: $1^{\text {st }}$ January $2012-31^{\text {st }}$ August 2017 (203 trades generated) for trending (non-choppy) market situations - correlation with volatility (\%) (Barron's, 2017; Tsoutsoura, 2004).

Table 2. CSR/CSE Green Products - Backtesting results for CSR ethics firms from the CSR green products category. Backtesting procedure: $1^{\text {st }}$ January $2012-31^{\text {st }}$ August 2017

\begin{tabular}{ccccc}
\hline \multicolumn{5}{c}{ Back-testing Results on USA Sector ETFs } \\
\hline USA Sector ETF & Volatility $\%$ & No. of Trades & Hit Rate $\%$ & Average Trade $\%$ \\
\hline XLB & $9.2 \%$ & 203 & 52 & $1.27 \%$ \\
XLE & $10.4 \%$ & 203 & 64 & $1.91 \%$ \\
XLF & $10.6 \%$ & 203 & 46 & $-1.20 \%$ \\
XLI & $7.7 \%$ & 203 & 63 & $1.29 \%$ \\
XLK & $7.5 \%$ & 203 & 50 & $0.28 \%$ \\
XLP & $5.2 \%$ & 203 & 53 & $0.20 \%$ \\
XLU & $6.9 \%$ & 203 & 54 & $0.32 \%$ \\
XLV & $6.7 \%$ & 203 & 50 & $-0.08 \%$ \\
XLX & $7.3 \%$ & 203 & 51 & $0.19 \%$ \\
XLY & $7.4 \%$ & 203 & 58 & $0.13 \%$ \\
Average & & & 55 & $0.43 \%$ \\
Correlation with volatility $\%$ & & & 0.39 & $0.07 \%$ \\
\hline
\end{tabular}

Following Table 3 is referred to the introduced CSR Green Services morality ethics firms and presents, in summary, the Hit Rate (\%) and the Average Trade (\%) for the period: $1^{\text {st }}$ January $2012-31^{\text {st }}$ August 2017 (203 
trades generated) for trending (non-choppy) market situations - correlation with volatility (\%) (Barron's, 2017; Tsoutsoura, 2004).

Table 3. CSR/CSE Green Services - Backtesting results for CSR ethics firms from the CSR green services category. Backtesting procedure: $1^{\text {st }}$ January $2012-31^{\text {st }}$ August 2017

\begin{tabular}{ccccc}
\hline \multicolumn{5}{c}{ Back-testing Results on USA Sector ETFs } \\
\hline USA Sector ETF & Volatility $\%$ & No. of Trades & Hit Rate $\%$ & Average Trade \% \\
\hline XLB & $9.2 \%$ & 203 & 48 & $-0.25 \%$ \\
XLE & $10.4 \%$ & 203 & 55 & $0.77 \%$ \\
XLF & $10.6 \%$ & 203 & 53 & $0.23 \%$ \\
XLI & $7.7 \%$ & 203 & 41 & $-0.19 \%$ \\
XLK & $7.5 \%$ & 203 & 38 & $-1.15 \%$ \\
XLP & $5.2 \%$ & 203 & 46 & $0.11 \%$ \\
XLU & $6.9 \%$ & 203 & 50 & $-0.19 \%$ \\
XLV & $6.7 \%$ & 203 & 43 & $0.16 \%$ \\
XLX & $7.3 \%$ & 203 & 52 & $1.01 \%$ \\
XLY & $7.4 \%$ & 203 & 53 & $1.11 \%$ \\
Average & & & 48 & $0.16 \%$ \\
Correlation with volatility $\%$ & & & 0.43 & $0.27 \%$ \\
\hline
\end{tabular}

Finally, Table 4 is referred to the introduced CSR Transportation morality ethics firms and presents, in summary, the Hit Rate (\%) and the Average Trade (\%) for the period: $1^{\text {st }}$ January $2012-31^{\text {st }}$ August 2017 (203 trades generated) for trending (non-choppy) market situations - correlation with volatility (\%) (Barron's, 2017).

Table 4. CSR/CSE Green Transportation - Backtesting results for CSR ethics firms from the CSR green transportation category. Backtesting procedure: $1^{\text {st }}$ January $2012-31^{\text {st }}$ August 2017

\begin{tabular}{|c|c|c|c|c|}
\hline \multicolumn{5}{|c|}{ Back-testing Results on USA Sector ETFs } \\
\hline USA Sector ETF & Volatility $\%$ & No. of Trades & Hit Rate \% & Average Trade $\%$ \\
\hline XLB & $9.2 \%$ & 203 & 36 & $0.25 \%$ \\
\hline XLE & $10.4 \%$ & 203 & 48 & $-0.22 \%$ \\
\hline XLF & $10.6 \%$ & 203 & 43 & $-1.23 \%$ \\
\hline XLI & $7.7 \%$ & 203 & 35 & $0.19 \%$ \\
\hline XLK & $7.5 \%$ & 203 & 48 & $-0.05 \%$ \\
\hline XLP & $5.2 \%$ & 203 & 44 & $0.40 \%$ \\
\hline XLU & $6.9 \%$ & 203 & 45 & $-0.33 \%$ \\
\hline XLV & $6.7 \%$ & 203 & 38 & $0.29 \%$ \\
\hline XLX & $7.3 \%$ & 203 & 41 & $0.04 \%$ \\
\hline XLY & $7.4 \%$ & 203 & 42 & $0.05 \%$ \\
\hline Average & & & 42 & $-0.06 \%$ \\
\hline Correlation with volatility $\%$ & & & -0.02 & $-0.53 \%$ \\
\hline
\end{tabular}

\section{Comparative \& Correlative Performance Analysis}

A comparative, correlative and provisional return analysis, according to Tables 1, 2, 3, and 4, indicates that the Green Building CSR/CSE category performance is poor. Actually, it performs only on five (5) out of the ten (10) USA ETF sectors, with an average trade of $-0.31 \%$ and a $40 \%$ hit rate. The Green Products CSR/CSE category performance is profitable on seven (8) out of the ten (10) USA ETFs, with a positive $0.43 \%$ average trade and 55\% hit rate. The Green Services CSR/CSE category performance is profitable on six (6) out of the ten (10) USA ETFs, with a positive $0.16 \%$ average trade and $48 \%$ hit rate. Finally, the Green Transportation CSR/CSE category performance is profitable on six (6) out of the ten (10) USA ETFs, with a slightly negative $-0.06 \%$ average trade and 42\% hit rate (Domenico D'Errico, 2017; Tsoutsoura, 2004; Orlitzky, 2013).

Hence, according to Tables 1, 2, 3, and 4, the Green Building CSR/CSE performances are uncorrelated with ETF volatility, which means that no matter what the market historical volatility is, this category performance is poor (Vayanos \& Woolley, 2013). Even more, the Green Products CSR/CSE and Green Services CSR/CSE 
performances are positively correlated with the ETFs' historical market volatility. That is to say, these two CSR/CSE ethical categories perform better on volatile markets. Finally, the correlation results on the fourth Green Transportation CSR/CSE category, show that its trading performance is negatively correlated with market volatility (historically). So, trading ethical CSR firms belonging in this category (Green Transportation CSR/CSE) is much more profitable in case of less volatile markets (Tsoutsoura, 2004; Blackrock, 2010; Basdekidou, 2017a; Avellaneda \& Zhang, 2010; Basdekidou, 2017b).

\section{Conclusions \& Future Research}

According to the comparative and correlation return analysis presented in the previous Section, investing and trading CSR/CSE ethics firms, through the ETF financial instruments, depends both on market volatility and the hosted CSR category (Vayanos \& Woolley, 2013; Basdekidou, 2015; Basdekidou, 2016a; Domenico D'Errico, 2017; Basdekidou, 2016b; Basdekidou, 2017c; Tsoutsoura, 2004; Orlitzky, 2013). For the purpose of this paper we examine and analyze both (i) the trading return performance of four CSR categories (green building, green products, green services, and green transportation); and (ii) the correlation between the firm's trading performance of these four CSR/CSE categories and the underlined involved historical market volatility.

We conclude that, in relatively less volatile markets the Green Transportation CSR/CSE ethical firms display better results (i.e. long-term investing and trading returns). On the other hand, in strong market volatile situations it is better to trade (i.e. short-term trading) Green Products CSR/CSE and Green Services CSR/CSE firms. Finally, the Green Building CSR/CSE ethical firms are uncorrelated with the market volatility, as well as their performance is poor in all market cases. That is to say, Green Building CSR/CSE firms are not for long-term investing or short-term trading in US markets. Further future research could follow the same statistical approach and investigate (for the interest of trading) the correlation of market volatility into a number of other CSR/CSE categories like: Sustainability, Executive Sustainability, Renewable Energy, Green IT, Green ICT, etc.

\section{Acknowledgments}

I would like to thank the anonymous reviewers for their careful reading of the manuscript and their many insightful comments and suggestions. Also, the financial support (covering mainly the CoT/CFTC, Zacks, and the Barron's \& WSJ.com market data expenses) from the EU/LLP Programme "EPOCHE 2014" (with Project No. 2013-1-GR1-ERA10-15376) is gratefully acknowledged.

\section{Conflicts of Interest}

The author has not declared any conflict of interest with the companies, ETFs, and market quotes appeared on this article. Also, on writing and publishing this paper she has no position in any stocks, ETF, ETN and trading instruments mentioned.

\section{Disclaimer}

The approaches and trading strategies provided on this article are general information services for the public. The author is not an investment advisor, and she does not endorse or recommend any securities, ETFs or other investments. Market quotes and certain other information on this article, as well as reference materials or links to sites, have been compiled unbiased from publicly available sources believed to be reliable and are for general informational and research purposes only. The accuracy or completeness of the information, approaches, plans and trading strategies contained herein is not guaranteed and is not intended to be relied upon for investment purposes.

\section{References}

Ahn, D. H., Conrad, J., \& Dittmar, R. F. (2003). Risk adjustment and trading strategies. The Review of Financial Studies, 16, 459-485. http://dx.doi.org/ 10.1093/rfs/hhg001

Ang, A., Hodrick, R. J., Xing, Y., \& Zhang, X. (2006). The Cross-Section of Volatility and Expected Returns. Journal of Finance, 61, 259-299. http://dx.doi.org/10.1111/j.1540-6261.2006.00836.x

Angel, J. J., \& Rivoli, P. (1997). Does Ethical Investing Impose a Cost upon the Firm? A Theoretical Perspective. Journal of Investing, 6(4), 57-61. http://dx.doi.org/10.3905/joi.1997.57

Asness, C., Moskowitz, T. J., \& Pedersen, L. H. (2013). Value and Momentum Everywhere. The Journal of Finance, LXVIII(3), 929-985. The American Finance Association. http://dx.doi.org/10.1111/jofi.12021

Avellaneda, M., \& Zhang, S. (2010). Path-Dependence of Leveraged ETF Returns. SIAM Journal of Financial Mathematics, $1, \quad 586-603$ (Society for Industrial and Applied Mathematics). http://dx.doi.org/10.1137/090760805 
Barclay, M. J., \& Hendershott, T. (2003). Price Discovery and Trading After Hours. The Review of Financial Studies, 16(4), 1041-1073. http://dx.doi.org/10.1093/rfs/hhg030

Barron's Financial Investment News and Market Data. (2017). Retrieved from http://www.barrons.com/data; and http://www.wsj.com; and http://www.wsj.com/europe

Basdekidou, V. A. (2015). Functionality, Returns and Efficiency before and after the Debt Crisis: An Empirical Analysis of the Greek Stock Market (Unpublished doctoral dissertation). Bulgarian Academy of Sciences Economic Research Institute, Bulgaria.

Basdekidou, V. A. (2016a). IPO Trading with Short-term and Intraday Temporal Functionalities. Business and Economics Journal, 7(4). http://dx.doi.org/10.4172/2151-6219.1000257

Basdekidou, V. A. (2016b). Personalized Temporal Trading Functionalities Engaged in Calendar Market Anomalies: Empirical Evidences from the 2007 and 2009 Financial Crises. Journal of Business \& Financial Affairs, 5(4). http://dx.doi.org/10.4172/2167-0234.1000225

Basdekidou, V. A. (2017a). Seasoned Equity Offerings as Technical Market Anomalies: Long-Term Temporal Trading Functionalities. International Journal of Economics and Finance, 9(1), 96-105. http://dx.doi.org/10.5539/ijef.v9n1p96

Basdekidou, V. A. (2017b). The Overnight Return Temporal Market Anomaly. International Journal of Economics and Finance, 9(3), 1-10. http://dx.doi.org/10.5539/ijef.v9n3p1

Basdekidou, V. A. (2017c). The Momentum \& Trend-Reversal as Temporal Market Anomalies. International Journal of Economics and Finance, 9(5), 1-20. http://dx.doi.org/10.5539/ijef.v9n5p1

Basdekidou, V. A., \& Styliadou, A. A. (2017). Technical Market Anomalies: Leveraged ETF Trading with Daily and Intraday Temporal Functionalities. Business and Economics Journal, 8(1). http://dx.doi.org/10.4172/2151-6219.1000275

Blackrock, Inc. (2010). ETF Landscape Year End 2009 Preview Report. Retrieved from http://www.BlackRock.com

Campbell, J. Y., Giglio, S., Polk, C., \& Turley, R. (2014). An Intertemporal CAPM with Stochastic Volatility. London School of Economics and Political Sciences working paper, LSE London, UK. https://pdfs.semanticscholar.org/0044/748cabfc0ee3f7fdeea1992ce8efd7aaaa5f.pdf

Chemmanur, T. J., He, S., \& Hu, G. (2009). The role of Institutional Investors in Seasoned Equity Offerings. Journal of Financial Economics, 94, 384-411. http://dx.doi.org/10.1016/j.jfineco.2008.12.011

Cheng, M., \& Madhavan, A. (2009). The Dynamics of Leveraged and Inverse-Exchange Traded Funds. Journal of Investment Management, 7(4), 43-62. Retrieved from http://www.q-group.org/wp-content/uploads/2014/01/Madhavan-LeverageETF.pdf

D’Errico, D. (2017). Detecting Swings. Technical Analysis of Stocks \& Commodities, 35(6), 24-26, 39.

Direxion Investments. (2017). ETFs and Funds: Bold trades on Gold Miners - in either direction. Retrieved from http://www.direxioninvestments.com/; http://www.direxioninvestments.com/gold-miners

Edelen, R. M., Ince, O., \& Kadlec, G. B. (2015). Institutional Investors and Stock Return Anomalies. E- Journal SSRN. http://dx.doi.org/10.2139/ssrn.2359744

Elder, A. (2014). The new Trading for Living: Psychology, Discipline, Trading Tools and Systems, Risk Control, Trade Management. Wiley Trading Series, p. 312. Retrieved from http://eu.wiley.com/WileyCDA/WileyTitle/productCd-1118443926.html

Hemingway, C. A. (2002). An Exploratory Analysis of Corporate Social Responsibility: Definitions, Motives and Values. Research Memorandum, 34(1). The University of Hull Business School, UK. Retrieved on September 7, 2017, from https://www.researchgate.net/publication/242639405_An_Exploratory_Analysis_of_Corporate_Social_Res ponsibility_Definitions_Motives_and_Values

Hemingway, C. A. (2004). Personal Values as the Catalyst for the Corporate Social Entrepreneur. $17^{\text {th }}$ Annual European Business Ethics Network (EBEN) Conference. The Univ. of Twente, Enschede, The Netherlands.

Hemingway, C. A. (2014). Corporate Social Entrepreneurship: Integrity Within. Cambridge Academic Press, 2014. Cambridge, UK. Retrieved from http://www.cambridge.org/gb/academic/subjects/management/business-ethics/corporate-social-entrepreneur 
ship-integrity-within?format=pb

Hemingway, C. A., \& Maclagan, P. W. (2004). Managers' Personal Values as Drivers of Corporate Social Responsibility. Journal of Business https://doi.org/10.1023/B:BUSI.0000020964.80208.c9

Lefèvre, E. (2010). Reminiscences of a Stock Operator. (J. D. Markman, Annotated edition, p. 448). Hoboken, NJ: John Wiley \& Sons, Inc. (Original work published 1923). Retrieved from http://eu.wiley.com/WileyCDA/WileyTitle/productCd-0470481595.html

Leung, T., Lorig, M., \& Pascucci, A. (2015). Leveraged ETF implied volatilities from ETF dynamics. Retrieved from http://www.spdr-etfs.com

Little, P. K. (2010). Inverse \& Leveraged ETFs: Not Your Father's ETF. The Journal of Index Investing, 1(1), 83-89. http://dx.doi.org/10.3905/jii.2010.1.1.083

Livermore, J. (2001). How to Trade in Stocks (R. Smitten, Translation, p. 179). New York, NY: McGraw-Hill. $\begin{array}{lllll}\text { (Original work } & \text { published } & \text { 1940). } & \text { Retrieved }\end{array}$ https://www.amazon.com/How-Trade-Stocks-Business-Books/dp/0071469796

Lou, D., Polk, C., \& Skouras, S. (2016). A Tug of War: Overnight versus Intraday Expected Returns. London School of Economics and Political Sciences working paper, LSE London, UK. Retrieved from http://personal.lse.ac.uk/loud/overnightmom.pdf

Lovell, A. (2002). Moral Agency as Victim of the Vulnerability of Autonomy. Journal Business Ethics: An European Review, 11(1), 62-76. http://dx.doi.org/10.1111/1467-8608.0025

Malkiel, B. G. (2003). A Random Walk Down Wall Street (p. 463). New York, NY: W. W. Norton \& Company. Retrieved from http:// http://site.iugaza.edu.ps/wdaya/files/2013/

Moskowitz, T. J., Ooi, Y. H., \& Pedersen, L. H. (2012). Time series momentum. Journal of Financial Economics, 104, 228-250. http://dx.doi.org/ 10.1016/j.jfineco.2011.11.003

Nguyen, X. M., \& Tran, Q. T. (2016). Dividend Smoothing and Signaling Under the Impact of the Global Financial Crisis: A Comparison of US and Southeast Asian Markets. International Journal of Economics and Finance, 8(11), 118-123. http://dx.doi.org/10.5539/ijef.v8n11p118

Ogden, J. P., \& Wu, S. (2013). Reassessing the Effect of Growth Options on Leverage. Journal of Corporate Finance, 23, 182-195. http://dx.doi.org/10.1016/j.jcorpfin.2013.08.008

Orlitzky, M. (2013). Corporate Social Responsibility, Noise, and Stock Market Volatility. The Academy of Management Perspectives, 27(3), 238-254. Business School / University of South Australia, Adelaide, Australia. Retrieved from http://marcorlitzky.webs.com/Papers/orlitzky2013amp.pdf

Styliadis, A. D. (2007). E-learning Documentation of Historical Living Systems with 3-d Modeling Functionality. Informatica, 18(3), 419-446. Retrieved from http://www.mii.vu.lt/informatica/pdf/INFO686.pdf

Styliadis, A. D., \& Vassilakopoulos, M. G. (2005). A Spatio-Temporal Geometry-based Model for Digital Documentation of Historical Living Systems. Information \& Management, 42(2), 349-359. http://dx.doi.org/10.1016/j.im.2004.01.006

Thompson, J. L. (2002). The World of the Social Entrepreneur. The International Journal of Public Sector Management, 15(5), 412-431. https://doi.org/10.1108/09513550210435746

Trevina, L. K. (1986). Ethical Decision Making in Organizations: A Person-Situation Interactionist Model. Academy of Management Review, 11(3), 601-617. Retrieved from http://www.jstor.org/stable/258313

Tsoutsoura, M. (2004). Corporate Social Responsibility and Financial Performance. Applied Financial Project (Center of Responsible Business / Haas School of Business / University of California at Berkeley). Retrieved from http://escholarship.org/uc/item/111799p2

Van, E. (2017). Retrieved from https://www.VanEck.com

Vayanos, D., \& Woolley, P. (2013). An Institutional Theory of Momentum and Reversal. Review of Financial Studies, forthcoming. London School of Economics and Political Sciences working paper. LSE London, UK. Retrieved from http://personal.lse.ac.uk/vayanos/Papers/ITMR_RFS13.pdf

Wilder, W. J. Jr. (1978). New Concepts in Technical Trading Systems (p. 130). Hunter Publishing Company. Winston-Salem \& Greensboro, NC: Trend Research. Library of Congress Card Catalog No. 78-60759. Retrieved 
http://rls.bsd.com.br/ rls/Classicos/Welles\%20Wilder\%20-\%20New\%20Concepts\%20in\%20Technical\%20

Trading\%20Systems.pdf

Worden. (2017). Retrieved from http://www.tc2000.com/

\section{Notes}

Note 1. CSR - Corporate Social Responsibility. Also called Corporate Conscience, Corporate Citizenship or Responsible Business, is a form of corporate self-regulation integrated into a business model. CSR policy functions as a self-regulatory mechanism whereby a business monitors and ensures its active compliance with the spirit of the law, ethical standards and national or international norms. Critics questioned the "lofty" and sometimes "unrealistic expectations" in CSR or that CSR is merely window-dressing, or an attempt to pre-empt the role of governments as a watchdog over powerful multinational corporations. Political sociologists became interested in CSR in the context of theories of globalization, neoliberalism and late capitalism. Some sociologists viewed CSR as a form of capitalist legitimacy and in particular point out that what began as a social movement against uninhibited corporate power was transformed by corporations into a 'business model' and a 'risk management' device, oft en with questionable results. CSR is titled to aid an organization's mission as well as serve as a guide to what the company represents for its consumers. Business ethics is the part of applied ethics that examines ethical principles and moral or ethical problems that can arise in a business environment. ISO 26000 is the recognized international standard for CSR. Public sector organizations (the United Nations for example) adhere to the triple bottom line (TBL).

Note 2. CSE - Corporate Social Entrepreneurship. A CSE is someone or something (person or procedure) who attempts to advance a social agenda in addition to a formal job role as part of a corporation. CSEs may or may not operate in organizational contexts that are predisposed toward CSR. CSE concerns are with both the development of social capital and economic capital. The formal job role of a CSE may not necessarily be connected with CSR, nor does a CSE have to be in an executive or in a management position.

Note 3. EMH - Efficient Market Hypothesis. The efficient market hypothesis is an investment theory that states it is impossible to "beat the market" because stock market efficiency causes existing share prices to always incorporate and reflect all relevant information. According to the EMH, stocks always trade at their fair value on stock exchanges, making it impossible for investors to either purchase undervalued stocks or sell stocks for inflated prices. As such, it should be impossible to outperform the overall market through expert stock selection or market timing, and the only way an investor can possibly obtain higher returns is by purchasing riskier investments.

Note 4. ETF - Exchange Traded Fund. An ETF is a marketable security that tracks an index, a commodity, bonds, or a basket of assets like an index fund. Unlike mutual funds, an ETF trades like a common stock on a stock exchange. ETFs experience price changes throughout the day as they are bought and sold. ETFs typically have higher daily liquidity and lower fees than mutual fund shares, making them an attractive alternative for individual investors. Because it trades like a stock, an ETF does not have its Net Asset Value (NAV) calculated once at the end of every day like a mutual fund does.

\section{Copyrights}

Copyright for this article is retained by the author(s), with first publication rights granted to the journal.

This is an open-access article distributed under the terms and conditions of the Creative Commons Attribution license (http://creativecommons.org/licenses/by/4.0/). 